\title{
Definiteness \& perfectivity in telic incremental theme predications
}

\author{
Adrian Czardybon \& Jens Fleischhauer
}

\section{Introduction*}

Incremental theme verbs such as eat, drink, write or read are well known for the fact that the referential properties of the incremental theme argument affect the referential properties, i. e., telicity, of the predication (e. g. Krifka 1986, 1998 among others). If the incremental theme argument has quantized ${ }^{1}$ reference, as for example in the case of a singular count noun such as apple, the whole predication is telic (1a). If the incremental theme argument has cumulative reference, which is the case for bare plurals (apples) and mass nouns (soup), the whole predication is atelic $(1 \mathrm{~b}, \mathrm{c})$. The contrast in telicity is indicated by the interpretation of the time-span adverbial in ten minutes. Only (1a) allows for the relevant telic interpretation in which the time-adverbial indicates the time after which the process of eating is finished. Such an interpretation is not possible with (b) and (c) since neither apples nor soup indicate a specified quantity that introduces a natural endpoint of the event.

(1) a. Paul ate an/the apple in ten minutes.

b. \# Paul ate apples in ten minutes.

c. \# Paul ate soup in ten minutes.

\footnotetext{
* We want to thank Sebastian Löbner for his inspiring comments on the topic discussed in the paper and also on other topics ranging from specific questions on linguistics to non-academic topics. He has always provided us with help, support, and inspiring examples. This paper profited from fruitful discussion with John Beavers, Hana Filip, Thomas Gamerschlag, Doris Gerland, Albert Ortmann, Sergej Tatevosov, and Robert D. Van Valin, Jr. We further want to thank our informants Katina Bontcheva, Syuzan Sachliyan, Koen Van Hooste, Nikolai Skorolupov, Natalia Mamerow, Wilhelm and Ursula Czardybon, and Ewelina Lamparska, as well as the audience of CTF 2012 and two anonymous reviewers. The work on this topic was financed by the Deutsche Forschungsgemeinschaft through CRC 991 and was carried out in the member projects B1 'Verb Frames at the Syntax-Semantics Interface' and C2 'Conceptual Shifts: Statistical Evidence'.

1 The notions of 'quantization' and 'cumulativity' are defined in section 2.
} 
Languages provide different ways for the quantization of otherwise cumulative nouns, three of which are illustrated in (2). The numeral three in (2a) is used for the quantization of a plural count noun, while in (b) a container construction ( $a$ bowl of) is used for the quantization of a mass noun. Numeral constructions are restricted to plural count nouns, while container constructions are typical of mass nouns. In (c) it is illustrated that the definite article can be used for the quantization of plural count as well as mass nouns.

(2) a. Paul ate three apples in ten minutes.

b. Paul ate a bowl of soup in ten minutes.

c. Paul ate the apples/the soup in ten minutes.

Filip (2004, 2008) focuses on the contrast between Germanic and Slavic languages in realizing telicity of incremental theme predications. Most Slavic languages such as Russian, Polish, and Czech lack a grammaticalized definite or indefinite article, but in contrast to the Germanic languages they have a systematic distinction between perfective and imperfective aspect. Due to the lack of a definite article, Slavic languages cannot make use of the strategy illustrated in (2c) for the quantization of nouns. Instead, these languages use the aspectual opposition for the expression of the telicity contrast. As the Russian examples in (3) show, a telic interpretation of an incremental theme argument only arises if the verb is used in the perfective aspect $(3 a, c)$. An incremental theme verb in the imperfective aspect only yields an atelic interpretation, no matter whether the incremental theme argument is inherently quantized (singular count noun as in (3b)) or not (as in $(3 \mathrm{~d}))^{2}$

(3) a. On s”-el $l_{\mathrm{PF}}$ jabloko za čas.

he S-eat.PAST apple.Acc in hour

'He ate a/the (whole) apple in an hour.'

b. On el $l_{\mathrm{IMPF}}$ jabloko ( $\left.{ }^{*} z a \check{c} a s\right)$.

he eat.PAST apple.ACc in hour

'He ate/was eating an/the apple.'

2 Throughout the paper we indicate grammatical aspect with subscripts on the verb and do not indicate it in the glossing. The reasons for doing this will be discussed in section 3.1.

3 List of abbreviations: ACC: accusative, AUX: auxiliary, COP: copular, DEF: definite, GEN: genitive, IMPF: imperfective, LOC: locative, NEG: negation, PART: particle, PF: perfective, PL: plural, PREP: preposition, sG: singular. 
c. On $v y$-pil $l_{\mathrm{PF}} \quad$ vod-u za čas. he VY-drink.PAST water-ACC in hour 'He drank (all) the water in an hour.'

d. On pil $l_{\mathrm{IMPF}}$ vod-u ( ${ }^{*} z a$ čas). he drink.PAST water-ACC in hour 'He drank/was drinking water.'

Filip (2008) states that the Germanic and Slavic languages use two different strategies for realizing telicity of incremental theme verbs. For Germanic languages she proposes an object-encoding strategy, since quantization is marked on the object. Slavic languages on the other hand use a verb-encoding strategy, as the grammatical aspect of the verb triggers a telic reading of the predication. ${ }^{4}$ The similarities of the use of the definite article in Germanic languages and the perfective aspect in Slavic languages has been observed by different authors as Wierzbicka (1967) for Polish, Filip (1993/1999) for Czech, and Birkenmaier (1979) for Russian. Others such as Abraham (1997), Kabakčiev (2000), Leiss (2000) and Borer (2005) go even further and assume that the definite article and perfective aspect serve the same semantic function. Leiss (2000:14) explicitly proposes that the perfective aspect and the definite article are realizations of the same grammatical category, the only difference being that they are expressed at different parts of the sentence (on the verb in case of aspect and inside the object NP in case of the article). Filip $(1993 / 1999,2001)$ argues against an equation of the definite article and perfective aspect; in her view, both have different semantic functions.

In this paper, we follow Filip's view and argue against the assumption that the definite article and perfective aspect have the same semantic function. Therefore, we are looking at two Slavic languages, the Upper Silesian dialect of Polish and Bulgarian, which have a grammaticalized definite article in addition to the grammaticalized aspectual system. Given the assumption that the definite article and perfective aspect are expressions of the same grammatical category, one would expect that one of the two is redundant in Upper Silesian and Bulgarian for expressing telicity of incremental theme predications. However, we will show that both, the definite article and the perfective aspect, are relevant for realizing telicity of those predications and therefore are neither semantically equivalent nor redundant. We will also demonstrate that there are differences in the entailments of definiteness and totality (which is the semantic contribution of the perfective

4 It is not the case that perfective verbs always express telic predications which will be shown in section 3.1 . 
aspect) depending on whether a language uses (i) the definite article, (ii) perfective aspect or (iii) both of them for realizing telicity of incremental theme predications. This further supports the view that the definite article and perfective aspect have different semantic functions.

The paper proceeds as following: The next section deals with the aspectual composition of incremental theme verbs. In section 3 we focus on the semantics of the definite article and the perfective aspect. Upper Silesian and Bulgarian data are presented in section 4 to show that the definite article as well as the perfective aspect are required to get a telic incremental theme predication. Section 5 discusses the different entailments provided by the perfective aspect and the definite article. Section 6 provides the conclusion and a short outlook.

\section{Aspectual composition of incremental theme verbs}

Following Vendler (1957), verbs are distinguished into states, activities, achievements, and accomplishments. For the topic of this paper, only the contrast between activities and accomplishments is relevant. Both accomplishments and activities describe dynamic situations but differ with regard to telicity. Accomplishments are telic and therefore express the attainment of a specific natural endpoint. Activities on the other hand are atelic and do not entail the reaching of such an endpoint. Telic predicates license time-span adverbials that indicate the time after which the endpoint of the event has been reached. In (4a), a change from an unstable to a stable condition is denoted, and it is stated that after two days the physical condition is stable. Atelic predicates do not allow time-span adverbials in the same interpretation (4b), since they do not provide a natural endpoint that has to be reached in order to yield a true predication. Rather time-span adverbials indicate the time after which an event starts. Such an interpretation, however, arises with both atelic and telic predications.

(4) a. The physical condition of the patient stabilized in two days.

b. \# John ran in ten minutes.

A further property of telic predications is that they do not have the 'subinterval property.' This is reflected by the fact that the progressive does not entail the perfect form of the predication (5a). Not just any arbitrary change makes a telic predication true; rather, only if the changes lead to an attainment of the telos. Atelic predicates, on the other hand, have the subinterval property and therefore 
license the entailment from the progressive to the perfect (5b). Once the process has started, an atelic verb leads to a true predication.

(5) a. The physical condition of the patient was stabilizing when he died. $\nrightarrow$ The physical condition has stabilized.

b. John was running when he was interrupted. $\rightarrow$ John has run.

Verkuyl (1972), among others, notes that Vendler's classification does not apply to verbs as such, but rather to verbal predications consisting of a verb and its complements and adjuncts. In case of incremental theme verbs, the referential properties of the incremental theme argument (a term introduced by Dowty 1991 based on Krifka's work) affect the aktionsart of the whole predication. This is illustrated by the English example in (6). The predication in (6) shows the aktionsart properties of accomplishments and hence expresses a telic predication due to the referential properties of the incremental theme argument, which has a quantized reference. (7) is an activity and expresses an atelic predication. The incremental theme argument apples has cumulative reference.

(6) a. Peter ate an apple in ten minutes.

b. \# Peter was eating an apple in ten minutes. $\nrightarrow$ Peter ate an apple.

(7) a. \# Peter ate soup in ten minutes.

b. Peter was eating apples when he was interrupted $\rightarrow$ Peter ate apples.

Basically, three types of incremental theme verbs can be distinguished: (i) verbs of consumption such as drink, eat, (ii) verbs of creation like build and write and (iii) verbs of performance such as sing and read. Only the first two groups of verbs are strictly incremental (see Krifka 1998), which means that they cannot express a change affecting a single object more than once. In the remainder of the paper we concentrate on the first type of incremental theme verbs. The effect of the referential properties of incremental theme arguments on the whole predication is captured by the rule of aspectual composition as stated in (8).

(8) Aspectual composition of incremental theme predications: ${ }^{5}$

An incremental theme verb combined with a quantized incremental theme argument yields a telic predication, whereas if it combines with a cumula-

5 With regard to other verbs, for example, degree achievements, aspectual composition proceeds in a different way (cf. Kennedy 2012, among others). Kardos (2012) presents a detailed study of the differences between degree achievements, achievements, and accomplishments on the one hand and incremental theme verbs in aspectual composition in Hungarian on the other. 
tive incremental theme argument it yields an atelic predication (e. g. Krifka 1986, 1998, Filip 1993/1999, 2001).

The notions of 'cumulativity' and 'quantization' are defined (based on Krifka 1991) in (9) and (10), respectively. (' $\oplus$ ' is the mereological sum operator and ' $<$ 'stands for the mereological part-of relation.)

(9) Cumulativity: A predicate $P$ is cumulative iff $\forall x, y[P(x) \wedge P(y) \rightarrow P(x \oplus y)]$

(A predicate $P$ is cumulative iff it applies to two individuals $x$ and $y$, then it also applies to the sum of both.)

(10) Quantization: A predicate $P$ is quantized iff $\forall x, y[P(x) \wedge P(y) \rightarrow \neg y<x]$

(A predicate $P$ is quantized iff it applies to two individuals $x$ and $y$, none of them is a proper part of the other.)

Singular count nouns such as apple have a quantized reference. If something is an apple, no proper part of it is also an apple. But the noun apple does not have the property of cumulativity, since the sum of two apples cannot be denoted by apple again. Rather the plural form apples has to be used. The bare plural apples shows cumulative reference, since if one has a set of apples and combines them with a second set of apples, the whole can be denoted by apples again. On the other hand, apples is not quantized, since a proper subset of more than one apple falls under the predicate apples again. Mass nouns have the same referential properties as bare plurals.

In English and German, singular count nouns in referential contexts always require some kind of nominal determination such as the definite or indefinite article (11). Sentence (11b) is not ungrammatical, but only allows a kind-denoting interpretation of apple.

(11) a. Peter ate an/the apple.

b. \# Peter ate apple.

Mass nouns in English and German are incompatible with the indefinite article but can take the definite article (cf. Krifka 1991). The article is not required with mass nouns and shifts the noun towards a quantized interpretation. This leads to a telic incremental theme predication (12a). Plural count nouns are compatible with the definite article too, in which case they also yield a quantized interpretation. But if they are used without nominal determination, they have cumulative 
reference. Such a case leads to an atelic incremental theme predication (12b) as stated in (8).
a. Peter ate the apples/the soup in ten minutes.
b. Peter ate apples/soup ( ${ }^{*}$ in ten minutes).

For aspectual composition of incremental theme verbs, different semantic analyses have been proposed, such as Krifka's (1986, 1998) mereological approach or the degree-based approach by, for example, Hay et al. (1999), Caudal \& Nicolas (2005), Beavers (2006), Piñón (2008) and Kennedy (2012). Krifka's account is probably the most influential one and also served as a basis for the degree-based accounts. The central idea of Krifka's approach is that events as well as objects form a part structure and incremental theme verbs provide a mapping between the part structure of events and incremental theme arguments. Referential properties are transferred from the object on the event via the homomorphic mapping between the two. We do not go into further details of this approach, since we merely focus on the morphosyntactic devices for realizing telicity of incremental theme predications (but see Kardos 2012 for a recent comparison of the mereological and the degree-based approaches).

Turning to the Slavic languages now, in (13) the Russian mass noun sup (soup) is combined with an imperfective (a) and a perfective (b) verb. A telic reading results only in the latter case. As the example shows, there is no explicit quantization of the mass noun.
a. Ivan el $l_{\mathrm{IMPF}} \quad$ sup $\quad\left({ }^{*} z a \check{c} a s\right)$. Ivan eat.PAST soup.ACC in hour 'Ivan was eating/ate soup.'
b. Ivan s"-el $l_{\mathrm{PF}} \quad$ sup za čas. Ivan S-eat.PAST soup.ACc in hour 'Ivan ate (all) the soup in an hour.'

The accusative vs. genitive opposition has an effect on telicity of incremental theme predicates. For a telic interpretation, the incremental theme argument has to be marked with accusative case (13b). If the argument is in the genitive, only an atelic reading is possible (14a). The genitive gives rise to a partitive reading of the direct object.
a. On s”-el $l_{\mathrm{PF}} \quad x l e b-a \quad\left({ }^{*} z a \check{c} a s\right)$. he S-eat.PAST bread-GEN in hour 'He ate some bread.' 
b. *On el $l_{\mathrm{IMPF}} \quad x l e b-a$.

he eat.PAST bread-GEN

Russian restricts this case alternation to perfective verbs as indicated in (14b). Other Slavic languages, like Croatian and Serbian, allow the case alternation even with imperfective verbs (Mendoza 2004:229). In the following discussion, we restrict ourselves to incremental theme verbs in the accusative and do not further investigate the mentioned case alternation.

By comparing (12a) and (13b) one might be led to the assumption that the definite article in the Germanic languages and the perfective aspect in Slavic serve the same function, namely expressing 'totality' ${ }^{6}$, as held by Leiss (2000). Similar views are expressed by Borer (2005) and Kabakčiev (1984a, 2000), who state that the function of both is the same and only differ with regard to their overt realization. If totality is expressed via perfective aspect, it is marked on the verb and if it is expressed via definiteness, it is marked in the noun phrase. So far this is in accordance with Filip's (2008) distinction between object-encoding and verb-encoding languages. This distinction centers on the question as to whether nominal determination or verbal morphology is used for realizing telicity of incremental theme predications. The claim is not that Germanic languages are only object-encoding and Slavic languages are only verb-encoding, but that primarily nominal determination is relevant for realizing telicity of incremental theme predications in the Germanic languages and verbal morphology in the Slavic languages. $^{7}$

Filip explicitly rejects the view that perfective aspect and the definite article serve the same semantic function. In Filip's analysis perfective aspect is an expression of 'totality (of events),' but the definite article is not. We follow Filip's $(1993 / 1999,2005 b)$ analysis of perfective aspect on the one hand and go with Löbner's $(1985,2011)$ uniqueness approach of definiteness on the other hand. Both, perfectivity and definiteness, are discussed in more detail in the next section.

\section{Perfectivity and definiteness}

In this section, we provide a short discussion of the semantic contribution of perfective aspect and the definite article. In the process, we take a special look

6 The notion of 'totality' will be discussed in section 3.1.

7 There are further morpho-syntactic strategies for realizing telicity of incremental theme predicates as shown by Latrouite \& Van Valin (this volume) for Lakhota and Tagalog respectively. 
at the interaction between perfective aspect, the definite article, and incremental theme predications.

\subsection{Perfective aspect}

Grammatical aspect is a conventionalized way of expressing different perspectives or viewpoints on a situation. Often it is also called 'viewpoint aspect,' as, for example, in the work of Smith (1991). There is a general distinction between perfective and imperfective aspect. Perfective aspect is used to denote complete but not necessarily completed situations. Hence it does not express the notion of resultativity (cf. Comrie 1976). Rather, the focus is on the situation as a whole without a distinction of its various phases. The imperfective aspect, on the other hand, is a cover term for different ways of denoting an incomplete or not necessarily complete situation. It comprises the habitual, continuous as well as progressive subtypes (see Comrie 1976). ${ }^{8}$

Germanic languages do not have a grammaticalized aspectual system, but some languages, such as English and Icelandic, have at least a grammaticalized progressive aspect (cf. Thieroff 2000). Other Germanic languages, like the north Frisian dialect Fering and German, are on the way towards grammaticalizing the progressive aspect (see Ebert 2000). All Slavic languages, on the other hand, have a systematic aspectual distinction between the perfective and the general imperfective aspect. The imperfective is used for the expression of the continuous, progressive, and habitual subtypes but also has a so-called 'denotative' use which is truth-conditionally equivalent to corresponding perfective sentences (see e. g., Isačenko 1962). Simplex verbs in Slavic languages are either imperfective, perfective or bi-aspectual (meaning that they allow for both aspectual interpretations depending on the context). There is no uniform marker of the perfective aspect in Slavic languages (cf. Isačenko 1962, Filip 1993/1999). Rather, a set of affixes, but also other devices such as suppletive stems or vowel changes are used for realizing the perfective aspect. Verbal prefixes are derivational affixes since they often alter the meaning of the base verb. Following Filip (1993/1999, 2000), prefixes are used to derive new verbs which can be perfective. This is illustrated by the Russian example in (15a) and the Bulgarian one in (b). (15a) shows the derivation of a perfective verb from a simplex imperfective verb by prefixation. The Bulgarian example in (15b) shows (i) that prefixes can be attached to simplex

\footnotetext{
8 Filip \& Carlson (1997) argue against the view that 'habitual' is a subtype of imperfective aspect.
} 
perfective verbs and (ii) that stacking of prefixes is possible. Bulgarian allows an iteration of up to seven prefixes (e. g., Istratkova 2004), and in cases such as porazdam it cannot be said that the prefixes contribute perfective aspect since the verb they attach to is already perfective. Thus, in both cases in (b) the prefix has a semantic but no aspectual effect on the verb.

$$
\begin{aligned}
& \begin{array}{l}
\text { a. } \text { pisat }_{\mathrm{IMPF}}^{\prime}-\text { pere-pisat }_{\mathrm{PF}}^{\prime} \\
\text { write } \\
\text { copy/rewrite }
\end{array} \\
& \begin{array}{l}
\text { b. } \text { dam }_{\mathrm{PF}}-\text { po-dam }_{\mathrm{PF}}-\text { po-raz-dam }_{\mathrm{PF}} \\
\text { give } \\
\text { pass }
\end{array}
\end{aligned}
$$

(Istratkova 2004: 309)

According to Filip, the only true aspectual marker in Slavic languages is a suffix indicating secondary imperfective aspect. ${ }^{9}$ This suffix attaches to perfective verbs and always yields an imperfective predication. Secondary imperfectivization is illustrated in (16) for the Bulgarian verb piša (write). The simplex verb piša is imperfective, by prefixing $n a$ - a perfective verb is derived from which one gets a secondary imperfective by adding the suffix $-v a$. In the following, we do not take secondary imperfectives into consideration, since they behave differently with respect to definiteness and telicity than nonsecondary imperfectives (cf. Filip 2005a).

$$
\begin{aligned}
& p i s ̌ a_{\mathrm{IMPF}}-n a-p i s ̌ a_{\mathrm{PF}}-n a-p i \check{s}-v a-m_{\mathrm{IMPF}} \\
& \text { write }
\end{aligned}
$$

Following Filip (1993/1999, 2005b), the perfective aspect is semantically represented by means of a totality operator (TOT). Filip (2005b: 134) notes that " $[\mathrm{t}]$ he effect of $\operatorname{TOT}(P)$ is to individuate atomic events in the denotation of a perfective verb, given that it is required that no two events in the denotation set of a given predicate $P$ overlap." Intuitively, TOT applied to a predicate $\mathrm{P}$ denotes events conceived as a single whole (Filip 2005b: 134), which means that the events are conceived as atomic and therefore no reference to its various phases can be made. (For the formal definition of the totality operator see Filip (2005b)).

With incremental theme verbs the totality operator sets certain requirements on the incremental theme argument. A perfective incremental theme verb always requires a quantized incremental theme argument. Filip (2005b:134f.) states:

\footnotetext{
9 Since affixes cannot be analyzed as aspectual markers, aspect is subscripted to the verb in our examples.
} 
"[g]iven that the perfective verb has total events in its denotation, the [homomorphic] mappings [between the event and the object] dictate that the Incremental Theme argument must refer to totalities of objects falling under its description." If the incremental theme argument is a singular count noun, this constraint is fulfilled. However, in order to achieve this constraint with cumulative nouns, they have to be shifted to a totality interpretation. The totality interpretation of mass nouns would account for the maximal quantity of stuff like for example 'water'. For such a maximal quantity interpretation, a specified context-dependent quantity of the referent of the mass noun is required. In the case of plural count nouns, the totality refers to the maximal group of some specific entities such as 'apples.' A description of the respective type shifting processes, based on Link's $(1983,1987)$ lattice theoretic logics of plurals and mass terms, can be found in Filip (1993/1999, 2005b).

In the context of the current discussion, it is relevant to note that the primary function of the perfective aspect is to express totality (of events) and that quantization is only secondary by imposing restrictions on the incremental theme argument of the verb. More specifically, quantization is achieved by a totality interpretation of inherently cumulative nouns. This also interacts with definiteness, as can be observed in the Russian examples in (17). Mass and plural count nouns as incremental theme arguments of perfective verbs get a definite interpretation (17a), while they get a partitive (indefinite) interpretation with imperfective verbs (17b).

a. On vy-pil $l_{\mathrm{PF}}$ vod-u. he VY-drank water-AcC

'He drank (all) the water.'

b. On pil IMPF $_{\text {vod-u. }}$

he drank water-Acc

'He drank/was drinking (some) water.'

Perfectivity does not induce a definite reading of singular count nouns, as the Russian examples in (18) show. Rather, singular count nouns allow for a definite as well as indefinite interpretation irrespective of grammatical aspect (as seen in (a) and (b)). Perfective aspect only induces a totality interpretation. In (18a) it is expressed that an/the whole apple was eaten.
a. On s"-el $l_{\mathrm{PF}}$ jabloko.
he S-ate apple.Acc
'He ate a(n)/the (whole) apple.' 
b. On el $l_{\text {IMPF }}$ jabloko.

he ate apple.Acc

'He ate/was eating an/the apple.'

As stated above, the effect of the perfective aspect is to mark totality (of events) and neither the quantization of nouns nor the expression of definiteness. Both quantization and definiteness are side effects of the totality interpretation of incremental theme arguments and they only arise in certain contexts, namely with cumulative direct object arguments of perfective incremental theme verbs. To be more precise, definiteness is a side effect of quantization and since singular count nouns are quantized, they are not obligatorily conceived as definite if they occur as the direct object of perfective incremental theme verbs. But it is also crucial to note that we distinguish between perfectivity and telicity, following Borik (2006) among others and in contrast to Kabakčiev (1984b, 2000), for example. As shown in the mentioned literature outside of the domain of incremental theme verbs, imperfective predications can be telic (19a) and perfective predications are not necessarily telic but can be atelic (19b).

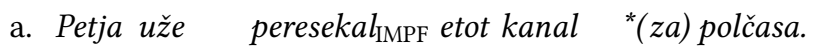

Peter already crossed this channel in half-hour

'Peter (has) already crossed this channel in/ ${ }^{*}$ for half an hour.'

(Borik 2006: 9)

b. Petja pro-sidel $l_{\mathrm{PF}} v$ tjur'me ( $\left.{ }^{*} z a\right)$ pjat' let.

Peter PRO-sit in prison.LOC in five years

'Peter was in prison for $/{ }^{*}$ in five years.'

(Borik 2006: 11)

\subsection{Definite article}

All Germanic languages exhibit a definite article (cf. König \& van der Auwera 1994) but differ with respect to the morphosyntactic realization. In the West Germanic languages such as English, Dutch, and German, the definite article is a free morpheme while in the Northern branch (Norwegian, Swedish, Danish, Faroese, and Icelandic) a free as well as a suffixed article can be found. The distribution of these articles is influenced by syntactic and semantic factors (Ortmann 2014). The following examples illustrate the syntactically governed distribution of the articles in Danish. The suffixed article is used if the noun is not pre-nominally modified (20a), whereas the free-form article is chosen in case of a modified noun (20b). 

a. hus-et
house-DEF
'the house'
b. det gamle hus
DEF old house
'the old house'
(Lyons 1999: 77)

In contrast, for the Slavic languages the lack of a definite article is said to be a characteristic property of this language family. However, there are some exceptions such as the two South Slavic languages Macedonian and Bulgarian, as well as two varieties of West Slavic namely Upper Silesian Polish (Czardybon 2010) and Colloquial Upper Sorbian (Breu 2004, Scholze 2008). Bulgarian exhibits a suffixed definite article which is attached to a noun (21a) or the first prenominal element of an NP (21b). In Upper Silesian on the other hand the definite article is realized as a free morpheme (22).

a. Papa-ta e glavana cărkva-ta. pope-DEF AUX head PREP church-DEF 'The Pope is the head of the Catholic Church.'

b. Toj ima moja-ta červena kniga. he has my-DEF red book 'He has my red book.' (lit. 'He has my the red book')

(22) Na tym piyrsz-ym zdjynciu jest Róża. PREP DEF first-LOC photo.LOC COP Róża 'Róża is on the first photo.'

With respect to the semantics of the definite article there are two main approaches, known as 'familiarity' and 'uniqueness,' which try to explain its function. ${ }^{10}$ Here, we follow Löbner $(1985,2011)$ for whom unique reference is the underlying concept of definiteness. In his analysis of definiteness, Löbner argues that the definite article has only one function, independent of whether it is used with a count or mass noun and whether the count noun is used in the singular or plural (Löbner 1985: 280). Essentially, definiteness expresses unique reference, in the sense of non-ambiguity of reference. Following Löbner $(1985,2011)$ two types of definite-

\footnotetext{
${ }^{10}$ For an overview of the two approaches, see Lyons (1999) and Abbott (2010).
} 
ness exist: semantic and pragmatic definiteness. ${ }^{11}$ A noun has semantic definite reference if its definite interpretation is not dependent on the context of use. Pragmatic definiteness on the other hand arises through the context of use and Löbner (1985: 298) writes that in this case the non-ambiguity of reference essentially depends on the special situation. The noun Pope, for example, is semantically definite, since there is only one Pope at one time and therefore the noun refers unambiguously. A similar case is the noun mother (of) which has unique reference since each person only has one single mother. The difference between Pope and mother (of) is that in the latter case a relation between two individuals, the mother and the person who she is a mother of, is expressed. Löbner calls nouns such as Pope individual concepts, since they uniquely refer to an individual, while mother (of) is a functional concept as it expresses a functional relation (a one-to-one mapping) between individuals. ${ }^{12}$

Pragmatic definiteness is established through the context of use and requires a noun (or use of a noun) that does not provide unambiguous reference through its meaning alone. A case in point is daughter, since a person can have more than one daughter or even no daughter at all. If used, for example, in a superlative construction, daughter allows for unique reference (23).

\section{my eldest daughter}

There are two types of nouns which do not show inherently unique reference, these are relational concepts such as daughter and sortal concepts like woman. Relational concepts provide a relation, in a similar manner to functional concepts, but no one-to-one mapping. Sortal concepts are non-relational and are clear instances of classifying nouns. The function of the definite article is to indicate that the respective noun is taken as a functional concept (Löbner 1985: 314). ${ }^{13}$ It either signals, in a redundant way, semantic uniqueness with individual and functional nouns, or signals pragmatic uniqueness with sortal or relational nouns.

Definite determiners are, as Löbner (1985: 281) argues, neutral with regard to the mass/count distinction. This means that the mass/count distinction is orthogonal to the concept type distinction he proposes (also see Löbner unpublished).

\footnotetext{
${ }^{11}$ Löbner (2011) is speaking of 'semantic' and 'pragmatic uniqueness' since uniqueness is the underlying concept for definiteness.

12 To be more precise, Löbner does not classify nouns but uses of nouns. The reason is that, for example, mother can also be used in a non-functional way as in Mothers are always helpful.

${ }^{13}$ Löbner (1985) takes individual nouns to be a subtype of functional nouns, while in Löbner (2011) they are taken as a class of its own.
} 
The class of sortal nouns encompasses, for example, woman as well as water. Also with regard to relational and functional nouns Löbner (1985: 294) states that they are not necessarily count nouns. Gamerschlag \& Ortmann (2007) mention the blood of an alligator as an example of a functional use of a mass noun. Clearly, this NP is non-quantized since any part of the blood of an alligator can be denoted by the same NP. There is still, however, the question as to whether the NP has cumulative reference. The answer depends on the effect of the definite article on mass nouns. Following Löbner (1985: 282), the "definite article indicates that the DD [definite description] refers to that, possibly complex, object to which the noun, as a predicate, applies in the situation referred to. The children refers to the entire complex object to which children applies; the child to the entire object to which child applies (which is necessarily only one child); and the snow to the entire object to which snow applies". The crucial question is what 'entire object' means. It surely does not mean that snow refers to all the snow in the world; rather it refers to a contextually specified portion of snow. The blood of an alligator does not need to refer to the entire blood of the alligator but only to, for example, a certain amount in a bottle. In this case we can add a further bottle of blood of the same alligator and refer to the sum of both as the blood of an alligator. Surely, the connections between Löbner's concept type distinction and the mass/noun distinction has to be further worked out, but this would go beyond the limits of the current paper.

Nevertheless, the marking of unique reference of cumulatively referring nouns leads to quantization by restricting the reference object of the noun to a specified quantity. While the bare mass noun water denotes the substance 'water', the water does not denote the entire substance 'water' but its reference is limited to a specific subportion. The exact quantity is context-dependent and could, for example, be a glass of, a bottle of, or three cups of. However, the water, without further linguistic or contextual specification, does not indicate the exact amount of water. This also applies to plural count nouns as in the case the books. With inherently quantized nouns, that is singular count nouns, the definite article only indicates unique reference since the noun already has a specified quantity reading. 


\section{Telicity strategies in Upper Silesian and Bulgarian}

The Upper Silesian and Bulgarian data in this and the following sections are provided by native speakers we consulted. The same holds for all other examples in the paper, where not indicated otherwise.

\subsection{Upper Silesian}

Upper Silesian, a south-west dialect of Polish, differs from standard Polish with regard to the grammaticalization of a definite article, which standard Polish lacks (Czardybon 2010). Authors such as Piskorz (2011) discuss the article status of standard Polish ten and claim that ten is on the way to being grammaticalized into a definite article due to its anaphoric use. However, we do not regard ten as a definite article since in anaphoric contexts demonstratives as well as definite articles can be used and are interchangeable as stated by Christophersen (1939:29) and Hawkins (1978: 149). We follow Himmelmann (2001: 833f.), for whom a determiner has developed into a definite article if its distribution is extended to associative-anaphoric or larger situation uses such as the sun, the Queen. As described in Chapter 3.2, these contexts are called semantically unique contexts by Löbner (2011). In these contexts, only definite articles can be used but not demonstratives which only mark definiteness redundantly due to the fact that the nouns are already semantically unique by themselves. As Polish ten is not extended to such contexts, we do not consider it to be a definite article.

In accordance with standard Polish and the other Slavic languages Upper Silesian has a fully grammaticalized aspect system. As shown in (24) the combination of a singular count noun and imperfective incremental theme verb always leads to an atelic predication. This is the case irrespective of whether a singular count noun such as jabko (apple) is used without (a) or with nominal determination (b). As (b) shows, the definite article is not sufficient to yield a telic interpretation if the verb is used in the imperfective aspect.

$$
\begin{aligned}
& \text { a. Łon jod } \text { IMPF }_{\text {jabk-o }} \text { ( }{ }^{*} z a \text { godzina). } \\
& \text { he eat.PAST apple-ACC.SG in hour }
\end{aligned}
$$

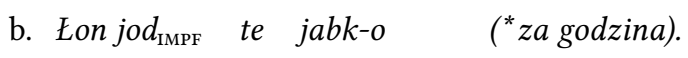

he eat.PAST DEF apple-ACC.SG in hour

'He ate/was eating (of) the apple.' 
As (25) shows, if the verb is used in the perfective aspect, the incremental theme predication becomes telic. The definite article is not required if a singular count noun is used as an incremental theme argument. Hence, examples (25a) and (25b) only differ with respect to definiteness of the direct object, but not with regard to telicity of the predication.

a. Eon $z$-jod $_{\mathrm{PF}} \quad$ jabk-o za godzina.

he Z-eat.PAST apple-Acc.sG in hour

'He ate an apple in an hour.'

b. Eon $z$-jod $_{\mathrm{PF}}$ te jabk-o za godzina.

he Z-eat.PAST DEF apple-ACC.SG in hour

'He ate the apple in an hour.'

If the incremental theme argument is a bare plural or a mass noun, the definite article is required for a telic predication $(26 \mathrm{~b}, 27 \mathrm{~b})$. Leaving out the definite article does not lead to ungrammatical sentences but (26a) and (27a) only have a kinddenoting and not a referential interpretation of the incremental theme arguments.

a. \# ton $z$-jod $_{\mathrm{PF}} \quad j a b k-a$.

he Z-eat.PAST apple-Acc.PL

'He ate [some plurality of the kind] apple.'

b. ton $z$-jod $_{\mathrm{PF}}$ te jabk-a za godzina.

he Z-eat.PAST DEF apple-ACC.PL in hour

'He ate the apples in an hour.'
a. \# Łon wy-piot prF $_{\mathrm{PF}} \quad$ woda.
he WY-drink.PAST water. ACC
'He drank [something of the kind] water.'
b. Eon wy-piot $t_{\mathrm{PF}}$ ta woda za godzina.
he WY-drink.PAST DEF water.ACC in hour
'He drank the water in an hour.'

Plural count nouns and mass nouns can combine with imperfective verbs without a definite article, as shown in (28). But as with singular count nouns (24) only an atelic interpretation is possible.
a. Łon jod $_{\mathrm{IMPF}} j a b k-a \quad\left({ }^{*} z a\right.$ godzina $)$.
he eat.PAST apple-ACC.PL in hour
'He ate/was eating (of) the apples.' 


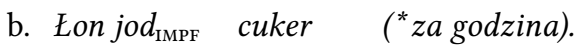

he eat.PAST sugar.ACC in hour

'He ate/was eating sugar.'

Thus, the data show that perfective incremental theme verbs always require a quantized incremental theme argument. Furthermore, a telic incremental theme predication only arises if the incremental theme argument is inherently or explicitly quantized and the verb is used in the perfective aspect.

\subsection{Bulgarian}

Bulgarian shows the same constraint on the combination of cumulative incremental theme arguments and perfective incremental theme verbs that was demonstrated for Upper Silesian. The examples in (29) show that imperfective incremental theme verbs do not require nominal determination of the incremental theme argument. Like in Upper Silesian, an imperfective verb does not lead to a telic predication if the incremental theme argument is definite (29b). As (c) demonstrates, the imperfective aspect is also compatible with quantized mass nouns, but does not give rise to a telic reading. ${ }^{14}$
a. Marija jade ${ }_{\mathrm{IMPF}}$ jabălka/ jabălki/ kaša ( ${ }^{*} z a$ edin čas).
Maria ate apple.sG/apple.PL/mash in one hour
'Maria ate/was eating (of) an apple/apples/mash.'

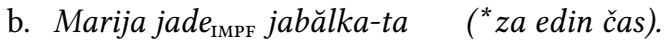
Maria ate apple. SG-DEF in one hour
'Maria ate/was eating (of) the apple.'
c. Marija jade $e_{\mathrm{IMPF}} k a s ̌ a-t a \quad\left({ }^{*} z a\right.$ edin čas).
Maria ate mash-DEF in one hour
'Maria was eating [some specific portion of] the mash.'

As in Upper Silesian, the combination of perfective incremental theme verbs and singular count nouns always leads to a telic predication (30), irrespective of the presence (30b) or absence (30a) of the definite article.

\footnotetext{
${ }^{14}$ Bulgarian shows a difference between the imperfect past tense and the aorist. Imperfective verbs are mainly used in the imperfect past, while perfective verbs show up mainly in the aorist. But as Kuteva (1995), for example, demonstrates, both past tenses can combine with perfective as well as imperfective verbs (also cf. Kabakčiev 2000).
} 
a. Marija iz-jade $e_{\mathrm{PF}}$ jabălka za edin čas. Maria IZ-ate apple.sG in one hour 'Maria ate an apple in one hour.'

b. Marija iz-jade ${ }_{\mathrm{PF}}$ jabălka-ta za edin čas.

Maria IZ-ate apple.sG-DEF in one hour 'Maria ate the apple in one hour.'

The contrastive pairs of sentences in (31) and (32) show that the combination of a perfective incremental theme verb and a cumulative noun only allows for a kind reading of the nominal. ${ }^{15}$ As in Upper Silesian the incremental theme argument needs to be quantized by, for example, the addition of the definite article for a referential and, in this case, also a telic interpretation.

a. \#Marija iz-jade $\mathrm{PF}_{\mathrm{PF}}$ jabălki.

Maria IZ-ate apple.PL

'Maria ate [some plurality of the kind] apple.'

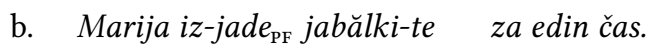

Maria IZ-ate apple.PL-DEF in one hour

'Maria ate the apples in one hour.'

a. \# Marija iz-jade $\mathrm{PF}_{\mathrm{PF}} k a s ̌ a$.

Maria IZ-ate mash

'Maria ate [something of the kind] mash.'

b. Marija iz-jade $e_{\mathrm{PF}} k a s ̌ a-t a ~ z a$ edin čas.

Maria IZ-ate mash-DEF in one hour

'Maria ate the mash in one hour.'

Upper Silesian and Bulgarian, then, behave alike with respect to the expression of telicity of incremental theme predicates. As claimed by Filip, perfective incremental theme verbs always require quantized incremental theme arguments. This is obvious in Upper Silesian and Bulgarian since perfective verbs cannot combine with referentially used bare plurals and mass nouns.

\subsection{Summary of telicity strategies}

So far, we have discussed the impact of the definite article and grammatical aspect in realizing telicity of incremental theme predications in Germanic and Slavic

${ }^{15}$ Guentchéva (1990:36) gives a Bulgarian example of a perfective incremental theme verb izpix 'drunk' used with a bare mass noun kafe 'coffee' which is judged by her as ungrammatical. She does not say anything about a possible kind reading of such constructions. 
languages. In Germanic languages, nominal determination, for example in the form of the definite article, is required to yield a telic predication. ${ }^{16}$ Nevertheless, the definite article is not sufficient to yield a telic predication, since it is also compatible with an atelic predication as (33) shows. Jackendoff (1996) states that if sentences such as (33) are acceptable with durative time adverbials then they do not imply that the object is totally consumed. Hay et al. (1999) state that examples such as (33) demonstrate that telicity is only an implicature in the case of verbs like eat (cf. Kardos 2012 for the view that incremental theme verbs in English and Hungarian show variable telicity similarly to degree achievements such as to cool).

(33) She ate the sandwich in/for five minutes.

(Hay et al. 1999: 139)

Kardos (2012: 152) mentions that incremental theme verbs in English only show variable telicity if the incremental theme argument has quantized reference and is combined with the definite or indefinite article (as in (33)). Variable telicity does not arise with cumulatively referring nouns (34a) or if a quantized noun is modified by a numeral construction or measure phrase (34b). This highlights again that the effect of the definite article with inherently quantized nouns only expresses unique reference and does not specify quantity.

a. Mary ate soup for 10 minutes $/{ }^{*}$ in ten minutes.

b. Kate ate three apples/two $\mathrm{kg}$ of apples in half an hour/??for half an hour. (Kardos 2012: 152)

Those Slavic languages that do not exhibit a definite article, for example Russian and Polish, make use of the perfective aspect to realize a telic incremental theme predication. The imperfective aspect of incremental theme verbs always leads to an atelic predication. Those Slavic languages that do have a definite article (Upper Silesian and Bulgarian) make primary use of the perfective aspect for expressing a telic incremental theme predication. The definite article is necessary in those cases in which the incremental theme argument is not inherently quantized. Thus, while the perfective aspect induces quantization of the incremental theme argument in Russian and Polish, in Upper Silesian and Bulgarian the ex-

\footnotetext{
${ }^{16}$ As already mentioned, the definite article is not the only way to quantize a cumulative noun, but we are only focusing on this strategy. In particular, we are leaving out a discussion of the indefinite article, which often goes parallel in quantization effects with the definite article but differs in its semantics.
} 
plicit quantization of bare plurals and mass nouns is required. Table 1 summarizes the strategies mentioned above.

\begin{tabular}{l|l|l} 
Language group & $\begin{array}{l}\text { telic incremental theme } \\
\text { predication }\end{array}$ & $\begin{array}{l}\text { atelic incremental theme } \\
\text { predication }\end{array}$ \\
\hline Germanic & + DEF & \pm DEF \\
\hline $\begin{array}{l}\text { Slavic I (without definite } \\
\text { article; e. g., Russian, Pol- } \\
\text { ish, Czech,...) }\end{array}$ & + PF & + IMPF \\
\hline $\begin{array}{l}\text { Slavic II (with a definite } \\
\text { article; Bulgarian, Upper } \\
\text { Silesian) }\end{array}$ & + PF & \\
\hline
\end{tabular}

Table 1: Summary of the different telicity strategies.

The discussion of the Upper Silesian and Bulgarian data reveals that the combination of the perfective aspect and the definite article is not redundant in realizing telicity. ${ }^{17}$ The exception to this are singular count nouns which are inherently quantized and hence do not require quantization via nominal determination. As mentioned in section 3.2 and further indicated above, we do not assume that the main function of the definite article consists in expressing quantized reference, but that quantization is a side effect due to unique reference. We will show in the next section that perfective aspect and the definite article license different entailments and therefore have different semantic contributions.

\section{Differences in entailments}

In this section we want to demonstrate that the definite article and perfective aspect make different semantic contributions to the overall incremental theme predication. Following Filip, we analyze perfective aspect as a totality operator on events. With respect to incremental theme predications, the perfective aspect entails that the referent of the incremental theme argument is totally affected. The Polish sentence in (35) expresses that the whole sandwich is consumed.

Ona $z$-jadta $a_{\mathrm{PF}} \quad k a n a p k-e$.

she Z-eat.PAST sandwich-ACC

'She ate a/the whole sandwich.'

17 This result is contrary to Abraham (1997: 60, n. 8), who states that the realization of perfective aspect and the definite article in Bulgarian merely represents a double marking of the same category. 
The definite article in Germanic languages does not induce a totally reading on the consumption process. This is demonstrated by the English example in (36) in which it is expressed that the sandwich was eaten but nevertheless something is left over. Hence the referent of the sandwich is not affected in totality. The Dutch (37) and Danish (38) examples exemplify the same point, which shows that this interpretation is not a peculiar fact of English. Due to the absence of perfectivity marking in Germanic languages, totality is merely an implicature since it can be cancelled.

(36) She ate the sandwich but as usual she left a few bites.

(Hay et al. 1999: 139)

Zij at het broodje maar zoals gewoonlijk at ze niet alles she eat.PAST DEF bread but as usual eat.PAST she NEG everything op.

PART

'She ate the sandwich/the bread but as usual she did not eat up everything.'

(38) Hun spiste sandwich-en, men som sædvanligt levnede hun nogle fä she eat.PAST sandwich-DEF but as usual left she some few bidder.

bites

'She ate the sandwich but as usual she left a few bites.'

Since the perfective aspect is overtly realized in Slavic languages, totality is not merely an implicature and therefore cannot be negated. This is demonstrated by the Polish (39) and Czech (40) examples. Stating that something of the food/drink is left over leads to a contradiction in Slavic languages, in contrast to the Germanic languages.

(39) \# Ona $z$-jadta $a_{\mathrm{PF}}$ kanapk-e, ale jak zwykle trochę zostawila. she Z-ate sandwich-Acc but as usual a bit left 'She ate a/the (whole) sandwich, but as usual she left a bit.'

(40) \# Ivan vy-pil $l_{\mathrm{PF}} \quad \check{c} a j$, ale ne-vy-pil $l_{\mathrm{PF}} \quad$ [ho/jej všechen]. Ivan VY-drank tea.ACc but NEG-VY-drank it all.ACC 'Ivan drank (up) [the whole portion of] tea, but he did not drink it all.' (Filip 2001: 463)

The data above reveal that a totality interpretation is only contributed by perfective aspect but not by the definite article. A further difference is that only the 
definite article but not perfective aspect leads necessarily to a definite interpretation of the incremental theme argument. This is, for example, shown by the Polish example in (35). The verb zjeść (eat) is perfective but the direct object kanapka (sandwich) has either a definite or indefinite reading. Example (41) from Slovak exemplifies the same point. Perfective incremental theme verbs only induce a totality interpretation of their incremental theme arguments, but for singular count nouns this is compatible with an indefinite interpretation. As discussed in section 3.1, plural count nouns and mass nouns always get a definite reading if used with a perfective verb. But as we argue there, the definite reading is only a side effect of quantization due to the totality reading. ${ }^{18}$
Diet'a zjedlo $o_{\mathrm{PF}}$ JABĹKO.
child eat.PAST apple
'The child ate an/the apple.'
(Späth 2006: 8)

As shown above, Germanic languages lack a totality interpretation of the incremental theme argument, but a definite interpretation trivially arises due to the definite article. The fact that Slavic languages induce a totality interpretation of the incremental theme argument, while the Germanic ones induce a definite interpretation that depends on differences in the grammaticalization of the perfective aspect and definiteness in these languages. Those Slavic languages that have a definite article necessarily induce a totality and definite interpretation of the incremental theme argument if the verb is used in the perfective and the definite article is present. The Upper Silesian examples in (42) and (43) show that a perfective verb entails totality. Expressing that a bit of the sandwich is left leads to a contradiction. The presence of the definite article in (42) only allows for a definite interpretation of the incremental theme argument. Its absence in (43) leads to an indefinite interpretation. Since Upper Silesian has a grammaticalized definite article as well as a perfective aspect, both definiteness and totality are semantically contributed, which distinguishes them from the Germanic and other Slavic languages.

(42) \# Eona $z$-jadła $a_{\mathrm{PF}}$ ta kanapka, ale jak zawsze zostawioła trocha. she Z-ate DEF sandwich but as usual left a bit 'She ate the/*a sandwich but as usual she left a bit.'

$\overline{18 \text { Capital letters indicate sentence stress. }}$ 
(43) \# Łona $z$-jadła $a_{\mathrm{PF}}$ kanapka, ale jak zawsze zostawioła trocha. she Z-ate sandwich but as usual left a bit

'She ate a/"the sandwich but as usual she left a bit.'

\section{Conclusion \& outlook}

In this paper we have discussed the role of the definite article and perfective aspect in the realization of telicity in incremental theme predications. Contrary to Leiss (2000), Borer (2005), and others, we argued that the definite article and perfective aspect serve different semantic functions. This was demonstrated by (i) the non-redundancy of the definite article and perfective aspect in the realization of telic incremental theme predications in Upper Silesian and Bulgarian (if the incremental theme argument is not inherently quantized) and (ii) the differences in the entailments that can be observed in languages that only use the definite article (Germanic), that only use the perfective aspect (most Slavic) and those languages that use perfective aspect as well as the definite article for realizing telicity (Upper Silesian and Bulgarian). The function of the definite article is to express uniqueness of the noun's referent, which has the effect of quantization as in the case of cumulative nouns. The perfective aspect is used to express totality, which requires quantized incremental theme arguments. To a certain extent, the effect of the definite article and perfective aspect overlap, nevertheless the data revealed that both serve different semantic functions.

One way to derive a perfective verb in Slavic languages is the use of prefixes. But in many cases, as discussed in 3.1, these prefixes change the semantics of the base verb. It is not always clear whether the telicity effect is solely dependent on perfective aspect or whether it depends on the additional lexical content the prefix adds to the base verb. The same effect of prefixes on telicity can also be observed in Germanic languages such as German. (44a) shows that the prefixed verb aufessen (eat up) forces a telic interpretation of the incremental theme verb. Furthermore, the example in (b) demonstrates that the prefixed verb is not compatible with cumulative nouns.

(44) a. Der Junge hat das Brot in fünf Minuten/ ( ${ }^{*}$ fünf Minuten lang) aufgegessen. DEF boy has DEF bread in five minutes five minutes long up.eaten 'The boy ate up the bread in five minutes/*for five minutes.'

b. * Der Junge hat Brote/ Suppe aufgegessen. DEF boy has breads soup up.eaten 
To exclude the possibility that telicity of incremental theme predications basically depends on the lexical content of the prefix and not (or not exclusively) on the perfective aspect, it would be worth investigating languages that express grammatical aspect as a purely inflectional category. One such language, which also has a grammaticalized definite article, is Arabic. An investigation of languages of such a type will be left open for the future.

\section{Bibliography}

Abbott, B. 2010. Reference. Oxford: Oxford University Press.

Abraham, W. 1997. The interdependence of case, aspect and referentiality in the history of German: the case of the verbal genitive. In A. van Kemenade \& N. Vincent (eds.), Parameters of morphosyntactic change, 29-61. Cambridge: Cambridge University Press.

Beavers, J. T. 2006. Argument/oblique alternations and the structure of lexical meaning: Stanford University dissertation.

Birkenmaier, W. 1979. Artikelfunktionen in einer artikellosen Sprache. Studien zur nominalen Determination im Russischen. München: Wilhelm Fink.

Borer, H. 2005. The normal course of events. Oxford: Oxford University Press.

Borik, O. 2006. Aspect and reference time. Oxford: Oxford University Press.

Breu, W. 2004. Der definite Artikel in der obersorbischen Umgangssprache. In M. Krause \& C. Sappok (eds.), Slavistische Linguistik 2002. Referate des XXVIII. Konstanzer Slavistischen Arbeitstreffens. Bochum 10. - 12.9.2002, München: Sagner.

Caudal, P. \& D. Nicolas. 2005. Types of degrees and types of event structures. In C. Maienborn \& A. Wöllstein (eds.), Event arguments: Foundations and application, 277-299. Tübingen: Max Niemeyer Verlag.

Christophersen, P. 1939. The articles. A study of their theory and use in English. Copenhagen: Munksgaard.

Comrie, B. 1976. Aspect: An introduction to the study of verbal aspect and related problems. Cambridge Textbooks in Linguistics. Cambridge: Cambridge University Press.

Czardybon, A. 2010. Die Verwendung des definiten Artikels im Oberschlesischen im Sprachvergleich. University of Düsseldorf MA thesis.

Dowty, D. 1991. Thematic proto-roles and argument selection. Language 67 (3). 547-619.

Ebert, K. 2000. Progressive markers in Germanic languages. In Ö. Dahl (ed.), Tense and aspect in the languages of Europe, 605-653. Berlin: Mouton de Gruyter. 
Filip, H. 1993/1999. Aspect, eventuality types and noun phrase semantics. New York/London: Garland.

Filip, H. 2000. The quantization puzzle. In C. Tenny \& J. Pustejovsky (eds.), Events as grammatical objects, 39-96. CSLI Publications.

Filip, H. 2001. Nominal and verbal semantic structure - analogies and interactions. Language Sciences 23. 453-501.

Filip, H. 2004. The telicity parameter revisited. In R. Young (ed.), Proceedings of SALT XIV, 92-109. Ithaca/NY, Cornell University.

Filip, H. 2005a. Measures and indefinites. In Gregory N. Carlson \& Francis Jeffry Pelletier (eds.), Reference and quantification, 229-288. Stanford: CSLI Publications.

Filip, H. 2005b. On accumulating and having it all. In Henk Verkuyl, Henriette de Swart \& Angeliek von Hout (eds.), Perspectives on aspect, 125-148. Dordrecht: Springer.

Filip, H. 2008. Events and maximalization: The case of telicity and perfectivity. In S. Rothstein (ed.), Theoretical and crosslinguistic approaches to the semantics of aspect, 217-256. Amsterdam/Philadelphia: John Benjamins.

Filip, H. \& G. Carlson. 1997. Sui generis genericity. Penn Working Papers in Linguistics 4. 91-110. The University of Pennsylvania. Philadelphia.

Gamerschlag, T. \& A. Ortmann. 2007. The role of functional concepts in the classification of nouns and verbs. Handout of a talk presented at the Conference "Concept Types and Frames 07.” 21 August 2007. University of Düsseldorf.

Guentchéva, Z. 1990. Temps et aspect: l'exemple du bulgare contemporain. Paris: Édition du centre national de la recherché scientifique.

Hawkins, J. A. 1978. Definiteness and indefiniteness. A study in reference and grammaticality prediction. London: Croom Helm.

Hay, J., C. Kennedy \& B. Levin. 1999. Scalar structure underlies telicity in "degree achievements". In T. Mathews \& D. Strolovitch (eds.), Proceedings of semantics and linguistic theory, vol. 9, 199-223. Ithaca/NY: Cornell Linguistic Circle Publications.

Himmelmann, N. 2001. Articles. In M. Haspelmath, E. König, W. Oesterreicher \& W. Raible (eds.), Language typology and language universals, 831-841. Berlin/New York: de Gruyter.

Isačenko, A. 1962. Die russische Sprache der Gegenwart. Halle (Saale): Niemeyer. Istratkova, V. 2004. On multiple prefixation in Bulgarian. Nordlyd 32.2. 301-321. 
Jackendoff, R. 1996. The proper treatment of measuring out, telicity, and perhaps even quantification in English. Natural Language and Linguistic Theory 14. 305-354.

Kabakčiev, K. J. 1984a. The article and the aorist/imperfect distinction in Bulgarian: an analysis based on cross-language 'aspect' parallelisms. Linguistics 22. 643-672.

Kabakčiev, K. J. 1984b. Verkuyl's compositional aspects and aspect in the Slavonic languages. Linguistique Balkanique XXVII. 77-83.

Kabakčiev, K. J. 2000. Aspect in English. Dordrecht: Kluwer.

Kardos, É. 2012. Toward a scalar semantic analysis of telicity in Hungarian: University of Debrecen dissertation.

Kennedy, C. 2012. The composition of incremental change. In V. Demonte \& L. McNally (eds.), Telicity, change, and state: A cross-categorical view of event structure, 103-121. Oxford: Oxford University Press.

Krifka, M. 1986. Nominalreferenz und Zeitkonstitution. Zur Semantik von Massentermen, Individualtermen, Aspektklassen. Munich, Germany: Universität München Dissertation.

Krifka, M. 1991. Massennomina. In D. Wunderlich \& A. von Stechow (eds.), Semantik, 399-417. Berlin: de Gruyter.

Krifka, M. 1998. The origins of telicity. In S. Rothstein (ed.), Events and grammar, 197-235. Dordrecht/Boston/London: Kluwer Academic Publishers.

Kuteva, T. 1995. Bulgarian tenses. In R. Thieroff (ed.), Tense systems in European languages, vol. II, 195-213. Tübingen: Niemeyer.

König, E. \& J. van der Auwera. 1994. The Germanic languages. London: Routledge. Latrouite, A. \& R. D. jr. Van Valin. 2014. Referentiality and telicity in Lakhota and Tagalog. In This volume, University of Düsseldorf. This volume.

Leiss, E. 2000. Artikel und Aspekt. Die grammatischen Muster von Definitheit. Berlin: de Gruyter.

Link, G. 1983. The logical analysis of plurals and mass terms. In R. Bauerle, Ch. Schwarze \& A. von Stechow (eds.), Meaning, use, and interpretation of language, 302-323. Berlin: de Gruyter.

Link, G. 1987. Algebraic semantics of event structures. In J. Groenendijk, M. Stokhof \& F. Veltman (eds.), Proceedings of the sixth Amsterdam Colloquium, 243272. Amsterdam: ITLI. University of Amsterdam.

Lyons, C. 1999. Definiteness. Cambridge: Cambridge University Press.

Löbner, S. 1985. Definites. Journal of Semantics 4. 279-326. 
Löbner, S. 2011. Concept types and determination. Fournal of Semantics 28(3). 279-333.

Löbner, S. unpublished. The semantics of nominals. Manuscript, University of Düsseldorf.

Mendoza, I. 2004. Nominaldetermination im Polnischen. Die primären Ausdrucksmittel. Habilitation thesis, LMU München.

Ortmann, A. 2014. Definite article asymmetries and concept types: semantic and pragmatic uniqueness. In T. Gamerschlag, D. Gerland, R. Osswald \& W. Petersen (eds.), Frames and concept types. Applications in language and philosophy, 293-321. Dordrecht: Springer.

Piskorz, K. 2011. Entsteht ein bestimmter Artikel im Polnischen? In M. Kotin \& E. Kotorova (eds.), History and typology of language systems, 159-168. Heidelberg: Winter Verlag.

Piñón, C. 2008. Aspectual composition with degrees. In L. McNally \& C. Kennedy (eds.), Adjectives and adverbs: Syntax, semantics and discourse, 183-219. Oxford: Oxford University Press.

Scholze, L. 2008. Das grammatische System der obersorbischen Umgangssprache im Sprachkontakt. Bautzen: Domowina - Verlag.

Smith, C. S. 1991. The parameter of aspect. Dordrecht, Boston, London: Kluwer Academic Publishers.

Späth, A. 2006. Determinierung unter Defektivität des Determinierersystems. Berlin: de Gruyter.

Thieroff, R. 2000. On the areal distribution of tense - aspect categories in Europe. In Oे. Dahl (ed.), Tense and aspect in the languages of Europe, 265-305. Berlin/New York: Mouton de Gruyter.

Vendler, Z. 1957. Verbs and times. The Philosophical Review 66. 143-160.

Verkuyl, H. 1972. On the compositional nature of the aspects. Dordrecht: Reidel Publishing Co.

Wierzbicka, A. 1967. On the semantics of the verbal aspect in Polish. In R. Jakobson (ed.), To honor Roman Jakobson. Essays on the occasion of his seventieth birthday, 2231-2249. The Hague: Mouton.

\section{Authors}

Adrian Czardybon

Jens Fleischhauer

Departement of Linguistics and Information Science

Heinrich-Heine-University Düsseldorf

\{czardybon,fleischhauer\}@phil.hhu.de 